\title{
Diagnosis and Treatment of Hypoglycaemia in the Newborn
}

\author{
MARIE A. CAMPBELL, ISOBEL C. FERGUSON, JAMES H. HUTCHISON, \\ and MARGARET $M$. KERR* \\ From the University Department of Child Health, and Queen Mother's Hospital, Glasgow
}

The importance of hypoglycaemia, defined as a true blood glucose below $20 \mathrm{mg} .100 \mathrm{ml}$., in the newborn infant is now well recognized. It is sometimes found in the idiopathic respiratory distress syndrome (RDS), in infants of diabetic mothers, and in neonatal cold injury, and it may also occur in association with anoxia, cerebral haemorrhage, or infection (Neligan, 1965). The majority of symptomatic cases, however, are 'idiopathic', though there is an obvious clinical association with 'dysmaturity' and intrauterine deprivation (Brown and Wallis, 1963). Shelley and Neligan (1966) stressed the value of the therapeutic test of giving 1 to $3 \mathrm{~g}$. glucose intravenously. Prompt disappearance of symptoms suggests that these were related to hypoglycaemia.

An associated problem is the possible significance of asymptomatic hypoglycaemia in some infants. Routine measurement of true blood glucose levels in all premature, dysmature, and other 'at risk' infants imposes a heavy load on a laboratory. The 'Dextrostix' enzyme test strip for estimation of the blood glucose has provided a possible screening test for the presence of hypoglycaemia. In addition, 'Dextrostix' tests allow of more frequent checks during treatment of a proven case of hypoglycaemia.

Initially, we used 'Dextrostix' only when symptoms suggested that an infant might be hypoglycaemic. Although the preliminary report on the use of 'Dextrostix' by Cohen, Legg, and Bird (1964) included very few readings where the true blood glucose was below $40 \mathrm{mg}$. $/ 100 \mathrm{ml}$., we have found that in all cases where the true blood glucose was below $20 \mathrm{mg}$. $/ 100 \mathrm{ml}$., the 'Dextrostix' recorded either less than $40 \mathrm{mg}$. $/ 100 \mathrm{ml}$., or 'doubtful'.

\footnotetext{
Received October 5, 1966.
}

$\star$ Requests for reprints should be addressed to Dr. M. M. Kerr, The Queen Mother's Hospital, Yorkhill, Glasgow C.3.

\section{Material and Methods}

In February 1965, it was decided to perform a 'Dextrostix' test on every infant immediately after admission to the Special-Care Nursery. The majority of these babies are admitted direct from the Labour Ward and in this group a second test is done 6 hours later, after which time many start oral feeding. Other infants are admitted to the department from the postnatal wards, from other maternity units, or from their own homes at varying ages up to 10 days. Again, a 'Dextrostix' check is made on admission and repeated in 6 hours in the few who are not feeding by that time. It was decided to continue checking at 6-hourly intervals in all babies whose feeding was further delayed for any reason. In addition, 'Dextrostix' tests are made at any time in infants who twitch, become apnoeic or cyanosed, or who exhibit any other abnormal behaviour. The tests are performed by both medical and nursing staff and the results recorded in the case records.

We report our findings with routine 'Dextrostix' testing in 1000 consecutive admissions to the SpecialCare Nursery between February and December, 1965. In addition, we report 15 cases of idiopathic symptomatic hypoglycaemia, 6 cases where hypoglycaemia coincided with other severe disorders, and 10 cases of asymptomatic hypoglycaemia. These 31 cases were seen in the period of 22 months from the opening of the hospital in January 1964 to March 1966.

True blood glucose was measured by the method of Marks (1959).

\section{Results}

Routine 'Dextrostix' tests in 1000 consecutive admissions. The infants can conveniently be considered in three different groups.

Group A: 787 babies admitted from the delivery rooms. Of these, $772 \mathrm{had}$ a 'Dextrostix' check on admission.

Group B: 115 babies admitted from the postnatal wards or from outside the hospital within 24 hours of birth. Of these, 107 were tested on admission. 
TABLE I

'Dextrostix' Readings Within 1 Hour of Birth-Group $A$

\begin{tabular}{|c|c|c|c|c|c|c|c|c|c|}
\hline & & \multicolumn{7}{|c|}{ 'Dextrostix' Readings (mg./100 ml.) } & \multirow{2}{*}{$\begin{array}{c}\text { Not } \\
\text { Done }\end{array}$} \\
\hline & & $<\mathbf{4 0}$ & 40 & 65 & 90 & 130 & 150 & 200 & \\
\hline $\begin{array}{l}\text { Mature }(622) \\
\text { Premature }(80) \\
\text { Dysmature }(85)\end{array}$ & $\begin{array}{l}\cdots \\
\cdots \\
\cdots\end{array}$ & $\begin{array}{l}2 \\
0 \\
0\end{array}$ & $\begin{array}{r}205(33) \\
45(60) \\
42(52)\end{array}$ & $\begin{array}{r}229(37) \\
21(28) \\
26(32)\end{array}$ & $\begin{array}{c}99(17) \\
6(8) \\
10(12)\end{array}$ & $\begin{array}{c}66(11) \\
3(4) \\
3(4)\end{array}$ & $14(2)$ & $\frac{1}{-}$ & $\begin{array}{l}6 \\
5 \\
4\end{array}$ \\
\hline Total (787) & $\cdots$ & 2 & 292 & 276 & 115 & 72 & 14 & 1 & 15 \\
\hline
\end{tabular}

Figures in parentheses are percentages.

Group C: 98 babies admitted from the wards or from outside aged 24 hours or more. Of these, 84 were checked on admission.

In certain cases the test was 'forgotten' or the result was not recorded. In Group A, 93\% had a repeat test done 6 hours later. This follow-up was incomplete, partly due to human error, but also because a few infants had died and others were having treatment which made the results inapplicable to the survey (e.g. intravenous fructose in the treatment of RDS).

In this paper a 'dysmature' infant is defined as one whose birthweight falls below the 10th centile for gestational age, according to the tables of Lubchenco, Hansman, Dressler, and Boyd (1963). We recognize that this definition will exclude a few infants who were thought clinically to be 'small for dates' (Lancet, 1966). Twins have been included. In 10 cases, with a birthweight of $2720 \mathrm{~g}$. or under, the gestation period was not known. These have not been included in the dysmature group. By 'premature' we mean an infant who, not being dysmature, weighed $2500 \mathrm{~g}$. or less at birth.

Group A. Table I shows the 'Dextrostix' readings immediately after birth (within 1 hour) in the 772 babies who were tested in Group A. Onethird of the mature infants and more than half of the prematures and dysmatures recorded at $40 \mathrm{mg}$. $/ 100$ $\mathrm{ml}$. The higher readings, mainly in mature babies, were generally related to intravenous glucose given to the mothers during labour, and it is, of course, well documented that the infant's blood glucose level at birth reflects that of the mother. None the less, 2 mature babies recorded at less than $40 \mathrm{mg}$./ $100 \mathrm{ml}$. One had a true blood glucose level of 11 mg./100 ml.; this infant had been severely asphyxiated at birth due to maternal accidental haemorrhage, but remained asymptomatic (Table VI, Case 2). The other was the infant of a diabetic mother and in this case the true blood glucose was $26 \mathrm{mg} . / 100 \mathrm{ml}$.

Table II shows the 'Dextrostix' readings 6 hours later in 721 of the babies. At this stage over $75 \%$ of all babies are reading at $40 \mathrm{mg}$. $/ 100 \mathrm{ml}$., and 7 were found to be less than $40 \mathrm{mg}$. Of these 7 , the 2 mature babies were found to have true blood glucose levels below $20 \mathrm{mg}$. $/ 100 \mathrm{ml}$. and both became symptomatic (Table V, Cases 8 and 9). The one premature baby had a gross acidosis associated with atelectasis and died, the hypoglycaemia being considered to be secondary and terminal. 3 of the 4 dysmature infants were confirmed as being hypoglycaemic: one, who had Rhesus incompatibility in addition, became symptomatic (Table V, Case 13); the other 2 remained asymptomatic (Table VI, Cases 3 and 8 ). The fourth dysmature baby had a laboratory reading of $35 \mathrm{mg} . / 100 \mathrm{ml}$.

Thus, from this group of infants, 9 were found to have 'Dextrostix' readings below $40 \mathrm{mg} . / 100 \mathrm{ml}$. by routine testing at birth and at 6 hours. Of these, 7

TABLE II

'Dextrostix' Readings at 6 Hours-Group $A$

\begin{tabular}{|c|c|c|c|c|c|c|c|c|c|}
\hline & & \multicolumn{7}{|c|}{ 'Dextrostix' Readings (mg./100 ml.) } & \multirow{2}{*}{$\begin{array}{c}\text { Not } \\
\text { Done }\end{array}$} \\
\hline & & $<40$ & 40 & 65 & 90 & 130 & 150 & 200 & \\
\hline $\begin{array}{l}\text { Mature (622) } \\
\text { Premature (80) } \\
\text { Dysmature (85) }\end{array}$ & $\begin{array}{l}\cdots \\
\cdots \\
\cdots\end{array}$ & $\begin{array}{l}2 \\
1 \\
4(5)\end{array}$ & $\begin{array}{r}443(76) \\
50(78) \\
67(87)\end{array}$ & $\begin{array}{c}118(20) \\
11(17) \\
5(7)\end{array}$ & $\begin{array}{c}11(2) \\
2(3) \\
1\end{array}$ & $\begin{array}{l}4(1) \\
-\end{array}$ & $\frac{1}{-}$ & $\frac{1}{-}$ & $\begin{array}{r}42 \\
16 \\
8\end{array}$ \\
\hline Total (787) $\quad \ldots$ & $\ldots$ & 7 & 560 & 134 & 14 & 4 & 1 & 1 & 66 \\
\hline
\end{tabular}

Figures in parentheses are percentages. 
TABLE III

'Dextrostix' Readings on Admission-Group B (Late admissions less than 24 hours old)

\begin{tabular}{|c|c|c|c|c|c|c|c|c|c|c|c|}
\hline & & & & \multicolumn{7}{|c|}{ 'Dextrostix' Readings (mg./100 ml.) } & \multirow{2}{*}{$\begin{array}{c}\text { Not } \\
\text { Done }\end{array}$} \\
\hline & & & & $<40$ & 40 & 65 & 90 & 130 & 150 & 200 & \\
\hline $\begin{array}{l}\text { Mature (86) } \\
\text { Premature (15) } \\
\text { Dysmature (14) } \\
\end{array}$ & $\begin{array}{l}. . \\
. .\end{array}$ & $\begin{array}{l}. \\
\because \\
\end{array}$ & $\because$ & $\frac{1}{1}$ & $\begin{array}{r}50(63) \\
11(79) \\
9(64) \\
\end{array}$ & $\begin{array}{r}22(28) \\
2(14) \\
4(3) \\
\end{array}$ & $\stackrel{5}{5}^{5(6)}$ & $\frac{1}{=}$ & 三 & 三 & $\begin{array}{r}7 \\
- \\
\end{array}$ \\
\hline Total (115) & .. & .. & .. & 2 & 70 & 28 & 6 & 1 & - & - & 8 \\
\hline
\end{tabular}

Figures in parentheses are percentages.

were shown to have true hypoglucosaemia, 3 being symptomatic.

The majority of babies were fed shortly after the age of 6 hours, and no further tests were done. In 26 mature babies, however, further checks were made, either because of twitching or other suggestive symptoms, or because their mothers were diabetic. 25 registered at $40 \mathrm{mg}$. $/ 100 \mathrm{ml}$. or over. The other, whose mother was diabetic, was checked because of twitching at the age of 20 hours. 'Dextrostix' failed to record, and the true blood glucose was found to be $26 \mathrm{mg}$. $/ 100 \mathrm{ml}$. 4 hours later, the true blood glucose level was $22 \mathrm{mg}$. and intravenous glucose was given. Despite this, 5 hours later the true blood glucose was reported as only $4.4 \mathrm{mg}$. $/ 100$ $\mathrm{ml}$. This symptomatic case is described in Table V, Case 10. 11 premature babies had further checks made and one recorded at less than $\mathbf{4 0} \mathrm{mg}$. Hypoglycaemia was confirmed but was asymptomatic (Table VI, Case 7). 10 dysmature babies had further checks made. Of these, 3 recorded at less than $40 \mathrm{mg}$. and all 3 were found to have true blood glucose levels below $20 \mathrm{mg}$. $/ 100 \mathrm{ml}$. One remained asymptomatic (Table VI, Case 4), one was symptomatic (Table V, Case 12), and in the third the hypoglycaemia was considered to be secondary to RDS and terminal. A further symptomatic case was detected at the age of 16 hours in a premature baby who had an extremely severe degree of Rhesus incompatibility (Table V, Case 7). Routine checks had not been made in the first 6 hours when attention was focused on resuscitation and slow exchange transfusion. She was finally checked with 'Dextrostix' because of the onset of twitching. One further asymptomatic case (Table VI, Case 10) was the infant of a diabetic mother. The true blood glucose level had been measured at the age of 23 hours as part of a separate investigation. Unfortunately, a simultaneous 'Dextrostix' check was not made. The previous 'Dextrostix' readings in the infant had been $40 \mathrm{mg}$. $/ 100 \mathrm{ml}$. at birth, and $65 \mathrm{mg}$. at the age of 6 hours.
Thus, from the 787 babies admitted to the department at birth, 14 cases of true hypoglycaemia were detected, 13 by the use of 'Dextrostix'. 6 of these were symptomatic.

Group B. Of the 115 babies in Group B, admitted within 24 hours of birth, 107 were checked on admission. The results are shown in Table III. Over $60 \%$ in all three categories were recording at $40 \mathrm{mg} . / 100 \mathrm{ml}$. The mature baby recording at less than $40 \mathrm{mg} . / 100 \mathrm{ml}$. was transferred from another hospital with RDS. Hypoglycaemia was confirmed but remained asymptomatic (Table VI, Case 5). The dysmature infant was also confirmed as hypoglycaemic, but was asymptomatic (Table VI, Case 6).

In 69 of the babies, subsequent checks were made and 3 recorded at less than $40 \mathrm{mg} . / 100 \mathrm{ml}$. In one of these, a mature baby, no true glucose was detectable in the laboratory, but he remained asymptomatic (Table VI, Case 1). This infant also had severe Rhesus incompatibility. He died on the fourth day with subarachnoid and intraventricular haemorrhage. The 2 others, one mature and one dysmature, both had evidence of severe brain damage. The confirmed hypoglycaemia was considered to be secondary in these cases. Both infants died.

Group C. Of the 98 babies in Group C, 84 were checked on admission. The findings are shown in Table IV. Among the mature babies there is much more variation in the 'Dextrostix' findings than in Group B but many were several days old and feeding had been established. The 3 mature babies with 'Dextrostix' readings below $40 \mathrm{mg} . / 100 \mathrm{ml}$. were all confirmed as being hypoglycaemic and all were symptomatic (Table V, Cases 11, 14, and 15).

To summarize, amongst the 1000 cases studied were 22 cases of hypoglycaemia, confirmed in the laboratory. 9 of these were symptomatic and would probably have been diagnosed in any case 
TABLE IV

'Dextrostix' Readings on Admission-Group C (Late admissions more than 24 hours old)

\begin{tabular}{|c|c|c|c|c|c|c|c|c|c|c|}
\hline & & & & & 'Dextrostix' & Readings (m & ml.) & & & Not \\
\hline & & 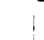 & $<40$ & 40 & 65 & 90 & 130 & 150 & 200 & \\
\hline $\begin{array}{l}\text { Mature }(80) \\
\text { Premature (11) } \\
\text { Dysmature (7) }\end{array}$ & $\begin{array}{l}\cdots \\
\cdots\end{array}$ & $\begin{array}{l}\cdots \\
\cdots \\
\cdots\end{array}$ & $\frac{3}{-}$ & $\begin{array}{r}25(36) \\
7(78) \\
4(80)\end{array}$ & $\begin{array}{l}21(30) \\
-\end{array}$ & $\begin{array}{l}14(20) \\
1 \\
1\end{array}$ & $\underline{-}^{6(9)}$ & 二 & 二 & $\begin{array}{r}10 \\
2 \\
2\end{array}$ \\
\hline Total (98) $\ldots$ & . & $\ldots$ & 3 & 36 & 22 & 16 & 6 & 1 & - & 14 \\
\hline
\end{tabular}

Figures in parentheses are percentages.

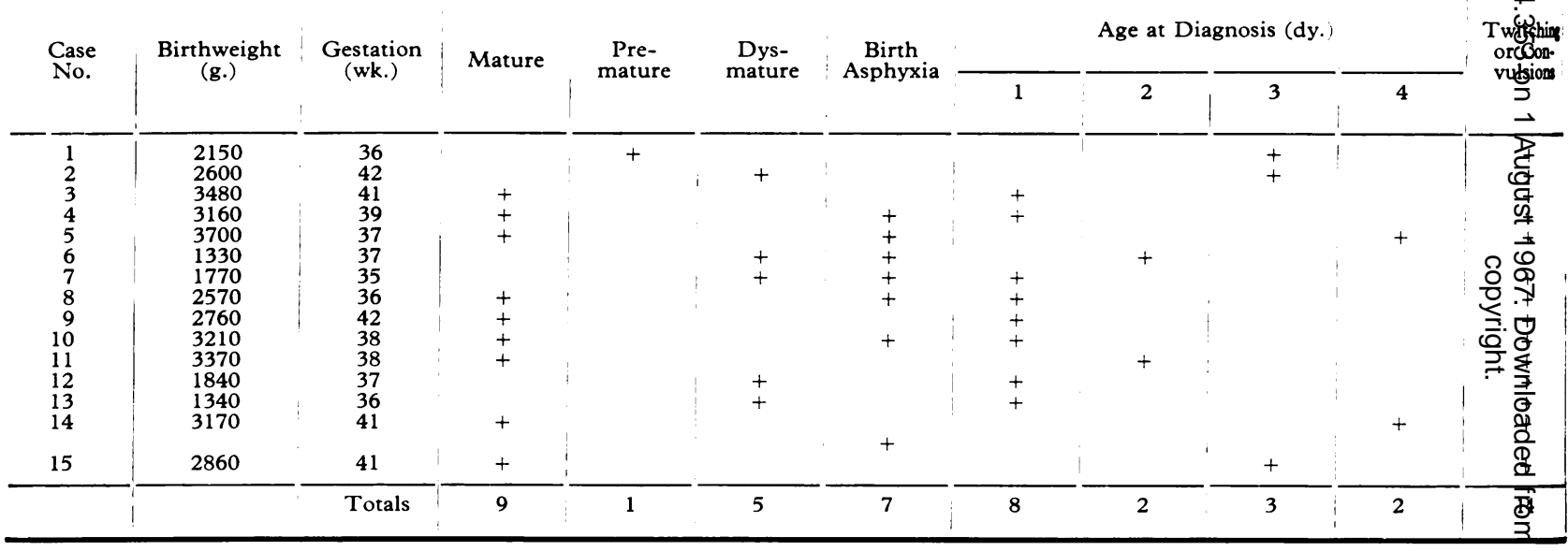

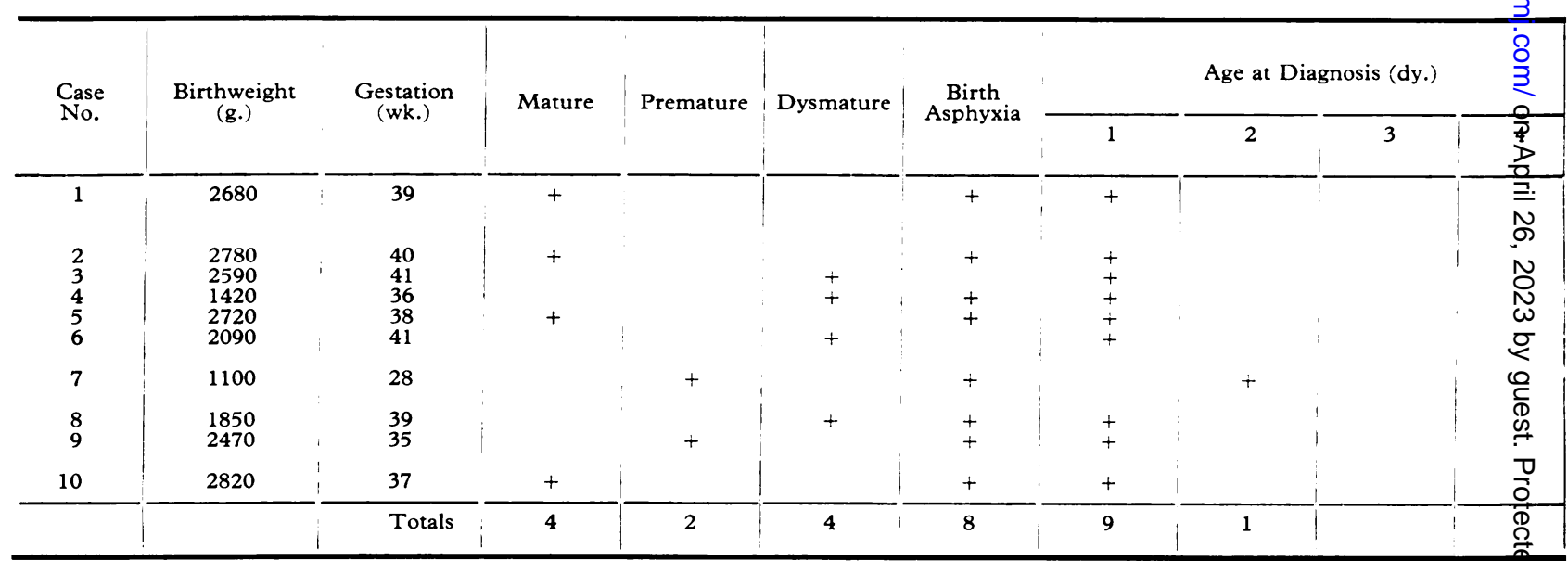


because of their symptoms; 9 were asymptomatic; in 4 cases the hypoglycaemia developed in infants who were dying of other severe disorders, and it was regarded as secondary to them.

Idiopathic symptomatic hypoglycaemia in the newborn ( 15 cases). Since the opening of the hospital in January 1964, 15 cases of symptomatic hypoglycaemia have been diagnosed ( 9 during the period of the 'Dextrostix' survey, 6 in Group A, 3 in Group C): 10 were male and 5 female. 11 of the 15 were born in the hospital, during which period there were 5178 live births, giving an incidence of $2 \cdot 1$ per
1000 , which approximates to that quoted by Neligan, Robson, and Watson (1963). The cases are shown in summary in Table V.

Of the 15 cases, 5 were dysmature and one premature. All were singletons, whereas Cornblath and Schwartz (1966) found an increased incidence in twins. In 14 cases twitchings or convulsions were predominant, and in 7 cases other suggestive symptoms - cyanosis, apnoea, or extreme lethargywere also present. An almost invariable symptom was troublesome vomiting.

Treatment. Intravenous fructose $\left(20_{\%}^{\circ}\right)$ was not

\begin{tabular}{|c|c|c|c|c|c|c|c|c|c|c|}
\hline \multirow{3}{*}{$\begin{array}{l}\text { Other } \\
\text { Symptoms }\end{array}$} & \multicolumn{7}{|c|}{ Treatment } & \multirow{3}{*}{ Remarks } & \multirow{2}{*}{\multicolumn{2}{|c|}{ Follow-up }} \\
\hline & \multicolumn{5}{|c|}{ Dextrose } & \multirow{2}{*}{$\begin{array}{l}20^{\circ} \circ \\
\text { Fructose } \\
\text { I.V. }\end{array}$} & \multirow{2}{*}{ Steroids } & & & \\
\hline & $\begin{array}{l}50^{\circ} \\
\text { I.V. }\end{array}$ & 1 & $\begin{array}{l}10^{\circ} 0 \\
\text { I.V. }\end{array}$ & $\begin{array}{l}20^{\circ} \mathrm{o} \\
\text { Orally }\end{array}$ & $\begin{array}{l}\text { Extra in } \\
\text { Feeds }\end{array}$ & & & & $\underset{\text { (mth.) }}{\text { Age }}$ & Result \\
\hline+ & & & & & & + & & & $\tau_{0}$ & - \\
\hline+ & & ! & & $\begin{array}{l}+ \\
+\end{array}$ & + & + & + & & $\begin{array}{r}9 \\
12\end{array}$ & $\begin{array}{l}\text { Retarded } \\
\text { Normal }\end{array}$ \\
\hline $\begin{array}{l}t \\
+\end{array}$ & & & $\begin{array}{l}+ \\
+\end{array}$ & + & + & & + & & 11 & Normal \\
\hline+ & $\begin{array}{l}+ \\
+\end{array}$ & & $\begin{array}{l}+ \\
+\end{array}$ & & + & & & & $\begin{array}{l}8 \\
4\end{array}$ & $\begin{array}{l}\text { Normal } \\
\text { Normal }\end{array}$ \\
\hline & + & & $\begin{array}{llll}+ \\
+\end{array}$ & & + & & & Severe $\mathrm{Rh}$ incompatibility & $\begin{array}{r}12 \\
2\end{array}$ & $\begin{array}{l}\text { Normal } \\
\text { Normal }\end{array}$ \\
\hline & + & & \pm & & & & + & Mother diabetic & $\begin{array}{r}13 \\
9\end{array}$ & $\begin{array}{l}\text { Normal } \\
\text { Normal }\end{array}$ \\
\hline+ & + & & \pm & & + & & + & Monol & 12 & Normal \\
\hline & $\begin{array}{l}+ \\
+\end{array}$ & 1 & \pm & + & $\begin{array}{l}+ \\
+\end{array}$ & & & $\mathrm{Rh}$ incompatibility & $\begin{array}{l}9 \\
1\end{array}$ & $\begin{array}{l}\text { Normal } \\
\text { Normal }\end{array}$ \\
\hline+ & & & & & + & & & Hypernatraemia & 5 & Retarded \\
\hline
\end{tabular}

VI

Hypoglycaemia

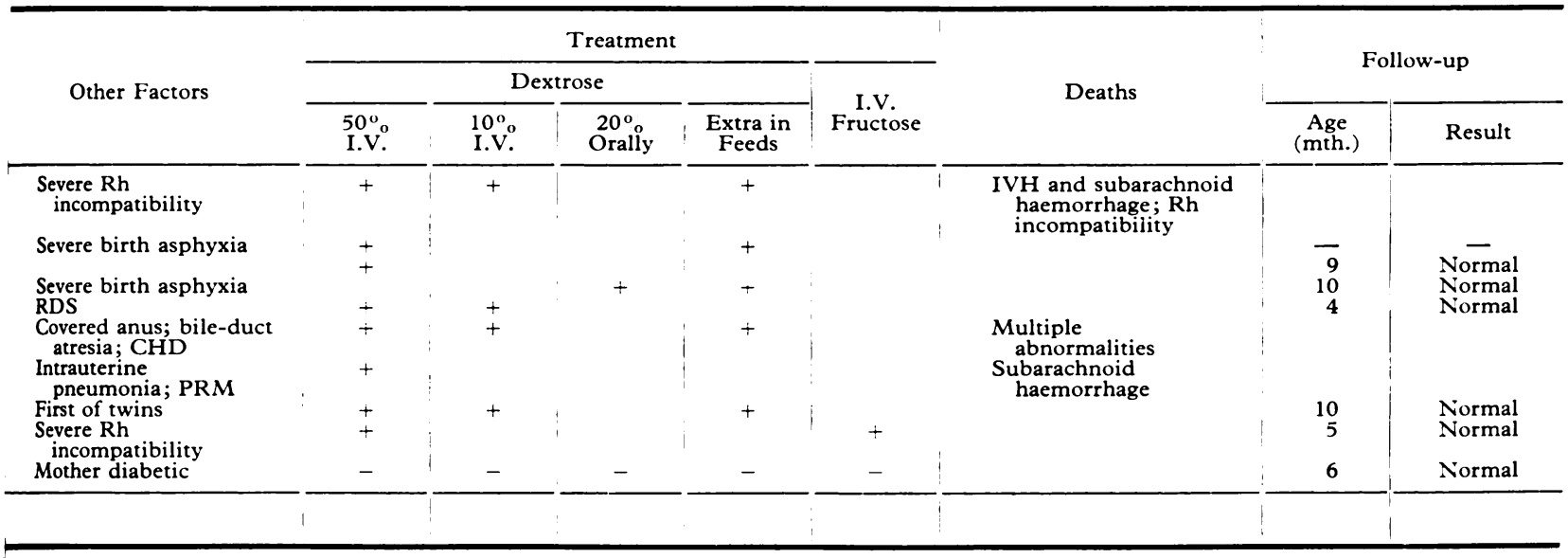


found to be a satisfactory method of raising the true blood glucose. It has been shown that babies with RDS are capable of metabolizing fructose to glucose (Hutchison, Kerr, Douglas, Inall, and Crosbie, 1964) and it was hoped that this nonirritant solution would be effective, but the infants in this series in whom fructose was used showed a very slow response in the blood glucose levels. Oral glucose, either as an intragastric drip or added to milk, was frequently accompanied by vomiting and is unsatisfactory and possibly dangerous. Prednisolone was used in only 4 cases. We consider that steroid therapy should be reserved for those cases where symptoms persist or where a satisfactory glucose level cannot be maintained. We are not convinced that it is effective in what appears to be a self-limiting condition. The most satisfactory treatment has proved to be one intravenous injection of $50 \%$ glucose $(5-10 \mathrm{ml}$.) followed by a scalp vein drip of $10 \%$ glucose in water at a rate of $60 \mathrm{ml} . / \mathrm{kg}$. 24 hours. If the intravenous dextrose has to be continued beyond 24 hours, it should then be dissolved in quarter strength physiological saline to prevent water intoxication. Oral feeding is continued or established and glucose $2 \cdot 5$ or $5 \mathrm{~g}$. may later be added to the feeds.

Results. All 15 babies survived. 3 have not been followed up-the mongol, an illegitimate baby, and one who defaulted (Table V, Cases 12, 1, and 14). Of the 12 remaining, 10 appear to be developing normally and 2 are retarded. One of the 2 , an illegitimate baby, was admitted on the third day from a mother and baby home. In addition to the hypoglycaemia he had diarrhoea and hyperelectrolytaemia (Table V, Case 15). The other was admitted from his home aged 60 hours with a history of cyanosis, lethargy, and vomiting of 30 hours' duration (Table V, Case 2). These results stress the value of early diagnosis and treatment.

Hypoglycaemia secondary to other neonatal disorders. In 6 cases ( 4 during the 'Dextrostix' survey period), hypoglycaemia was considered to have been secondary to other severe disorders. 4 were male; 2 were dysmature and one premature: all 6 babies died.

The following are brief reports of these cases.

Case I. Male, 3540 g., at 42 weeks. Severe birth asphyxia in a postmature infant born at home. At necropsy, cerebral venous congestion and bronchopneumonia were found. The latter was possibly associated with the use of mouth-to-mouth breathing.

Case II. Male, 1760 g., at 35 weeks. Premature rupture of membranes. Developed RDS. Treated with THAM and $20 \%$ fructose. Necropsy showed some hyaline membrane formation and an early bronchopneumonia.

Case III. Female, 2340 g., at 40 weeks. Transferred from another hospital because of Rhesus incompatibility. Collapsed during exchange transfusion. Necropsy revealed a massive subdural haemorrhage.

Case IV. Male, 1480 g., at 33 weeks. Membranes ruptured for 6 weeks before delivery. Apgar 2 . Respiration was established but there was a rapid deterioration. $X$-ray film showed gross atelectasis. A severe mixed metabolic and respiratory acidosis developed with $p \mathrm{H} 6 \cdot 73$. Necropsy showed atelectasis.

Case V. Male, 2830 g., at 36 weeks. Born in another hospital. Severe birth asphyxia associated with accidental haemorrhage. Respirations established following intubation and intermittent positive pressure. Admitted aged 8 hours in a moribund condition. 'Dextrostix' did not record and total blood sugar was $18 \mathrm{mg} . / 100 \mathrm{ml}$. Died 30 minutes after admission. Necropsy showed intense capillary congestion and alveolar haemorrhage in the lungs with hyaline membrane formation.

Case VI. Female, 3040 g., at 40 weeks. Born in another hospital. Severe birth asphyxia associated with accidental haemorrhage. Responded to intubation, but deteriorated 6 hours later and was again intubated. Admitted aged 8 hours. Unconscious and cyanosed with period of apnoea alternating with tachypnoea. 'Dextrostix' did not record. No true glucose was detectable in the laboratory. Severe metabolic acidosis and the hypoglycaemia were corrected, but there was minimal clinical improvement and the baby died aged 35 hours. Necropsy revealed gross bilateral adrenal haemorrhage, intraventricular haemorrhage, and extensive subarachnoid haemorrhage.

Asymptomatic hypoglycaemia (10 cases). Ten cases of asymptomatic hypoglycaemia were diagnosed between February 1965, when the 'Dextrostix' survey was started, and March 1966 (9 during the period of the 'Dextrostix' survey, 6 in Group A, 3 in Group B). 5 were male and 5 female. 4 were mature, 2 premature, and 4 dysmature. There was one twin. 3 babies died. The main features are summarized in Table VI. In several of the asymptomatic cases other disorders were present. These included 2 cases of Rhesus incompatibility and one of RDS.

\section{Discussion}

The 'Dextrostix' enzyme test strip provides a satisfactory and rapid method of detecting hypoglycaemia in newborn babies. It may be used as a check in infants with suggestive symptoms, and it is a useful screening test in the 'at risk' groups, e.g. those 'small for dates' and infants of diabetic mothers. The test can readily be done by members 
of both medical and nursing staff. It places no great load upon them and it ensures against delay in recognizing the presence of hypoglycaemia, thus reducing the risks of permanent brain damage (Anderson, Milner, and Strich, 1966; Chance and Bower, 1966). True blood glucose levels must of course be measured in the laboratory in all cases where the colour change is absent or 'doubtful' on the 'Dextrostix'.

At the age of 6 hours over $75 \%$ of all babies show a true blood glucose level of around $40 \mathrm{mg} . / 100 \mathrm{ml}$. 8 cases of true hypoglycaemia were detected by this age, but 7 further cases were found on later testing. Apart from 3 babies admitted from outside the hospital, all our cases of hypoglycaemia were noted within 48 hours of birth. Yu, Payne, Ifekwunigwe, and Stevens (1965), studying the biochemistry of premature babies in the first $\mathbf{4 8}$ hours of life, found that the 6 infants who weighed less than $1500 \mathrm{~g}$. all had a blood glucose level of less than $20 \mathrm{mg}$. $/ 100 \mathrm{ml}$. at some time during the first 24 hours. This suggests that 6 -hourly routine checking should be continued for $\mathbf{4 8}$ hours in the at-risk groups, whether or not feeding has been started, and this is now our practice.

The routine use of 'Dextrostix' makes early diagnosis of symptomatic hypoglycaemia easy, and permits the detection of asymptomatic cases and of those secondary to other severe diseases which might otherwise be missed. This simple test also encourages frequent monitoring of the blood glucose levels in infants under treatment when such are indicated. Indeed it is now practicable to correct hypoglycaemia in the newborn quickly, whether or not it is associated with overt symptoms. With the scalp vein needles and special drip sets now available, suitable therapy should present no technical problems in a Special-Care Department.

We have been impressed by the difficulty often experienced in the symptomatic cases in maintaining satisfactory blood glucose levels in spite of continuous intravenous administration. In some cases the disease has seemed to end abruptly after several days. This has caused us to doubt whether depletion of glycogen stores can be the only aetiological factor (Shelley and Neligan, 1966), and it seems at least probable that there may be a temporary immaturity of an enzyme system in some infants.

In the asymptomatic cases, which can only be detected by some form of routine testing, there is room for argument as to whether correction of the hypoglucosaemia is indicated. Presumably it is wise to do so in cases associated with other disorders, such as Rhesus incompatibility and RDS. In otherwise healthy infants, Shelley and Neligan (1966), referring to unpublished work of Neligan's, suggest that 'asymptomatic hypoglycaemia is unlikely to cause cerebral damage in babies', but they make the point that 'it is advisable to monitor the blood glucose concentration and to be ready to raise it as soon as clinical signs appear'. It is often difficult to decide whether or not symptoms are present, particularly in the smaller infants. The assessment of lethargy in a small premature baby may be difficult. The same applies to tremulousness. Since hypoglycaemia is known to be associated with brain damage, it seems wiser to correct it, particularly in the premature and others of low birthweight who show an increased incidence of mental retardation (Drillien, 1964). Our present practice is to treat asymptomatic cases when they are detected, and routine 'Dextrostix' testing makes it likely that few go unrecognized.

\section{Summary}

The 'Dextrostix' test was performed in a survey comprising 1000 consecutive admissions to a neonatal paediatric unit. It revealed 9 cases of symptomatic hypoglycaemia, 9 of asymptomatic hypoglycaemia, and 4 secondary to other severe diseases. It has proved to be a valuable screening test which encourages early diagnosis, and is within the competence of both medical and nursing staff.

Thirty-one cases of neonatal hypoglycaemia (including those detected in the above survey) have been analysed: 15 were symptomatic, 10 asymptomatic, and 6 secondary in nature. Their management is discussed.

We wish to thank the members of our nursing staff who have cheerfully accepted a further addition to their routine in the Special-Care Department.

\section{REFERENCES}

Anderson, J. M., Milner, R. D. G., and Strich, S. J. (1966). Pathological changes in the nervous system in severe neonatal hypoglycaemia. Lancet, 2, 372.

Brown, R. J. K., and Wallis, P. G. (1963). Hypoglycaemia in the newborn infant. ibid., 1, 1278.

Chance, G. W., and Bower, B. D. (1966). Hypoglycaemia and temporary hyperglycaemia in infants of low birthweight for maturity. Arch. Dis. Childh., 41, 279.

Cohen, S. L., Legg, S., and Bird, R. (1964). A bedside method of blood-glucose estimation. Lancet, $2,883$.

Cornblath, M., and Schwartz, R. (1966). Disorders of Carbohydrate Metabolism in Infancy. W. B. Saunders, Philadelphia and London.

Drillien, C. M. (1964). The Growth and Development of the Prematurely Born Infant. E. \& S. Livingstone, Edinburgh \& London.

Hutchison, J. H., Kerr, M. M., Douglas, T. A., Inall, J. A., and Crosbie, J. C. (1964). A therapeutic approach in 100 cases of the respiratory distress syndrome of the newborn infant. Pediatrics, 33, 956.

Lancet (1966). Small for dates. (Annotation.) 1, 1309. 
Lubchenco, L. O., Hansman, C., Dressler, M., and Boyd, E. (1963). Intrauterine growth as estimated from liveborn birthweight data at 24 to 42 weeks of gestation. Pediatrics, 32, 793.

Marks, V. (1959). An improved glucose-oxidase method for determining blood, CSF, and urine glucose levels. Clin. chim. Acta, 4, 395.

Neligan, G. A. (1965). Idiopathic hypoglycaemia in the newborn. In Recent Advances in Paediatrics, 3rd edn., ed. D. Gairdner, p. 110. Churchill, London.
—, Robson, E., and Watson, J. (1963). Hypoglycaemia in the newborn: a sequel of intrauterine malnutrition. Lancet, 1 , 1282.

Shelley, H. J., and Neligan, G. A. (1966). Neonatal hypoglycaemia. Brit. med. Bull., 22, 34.

Yu, J., Payne, W. W., Ifekwunigwe, A., and Stevens, J. (1965). Biochemical status of healthy premature infants in the first 48 hours of life. Arch. Dis. Childh., 40, 516. 